\title{
Applying the Successional Weed Management Model for Revegetating a Yellow Starthistle-Infested Dryland Pasture in the Chihuahuan Desert
}

\author{
William D. Sommers IV, ${ }^{1}$ Larry D. Howery, ${ }^{1}$ Rosemary L. Pendleton, ${ }^{2}$ Richard D. Lee, ${ }^{3}$ \\ and Burton K. Pendleton ${ }^{2}$ \\ ${ }^{1}$ School of Natural Resources and the Environment, The University of Arizona, Tucson, AZ 85721, USA \\ ${ }^{2}$ Rocky Mountain Research Station, USDA Forest Service, Albuquerque, NM 87102, USA \\ ${ }^{3}$ National Operations Center, Bureau of Land Management, Denver, CO 80225, USA
}

Correspondence should be addressed to Larry D. Howery, lhowery@ag.arizona.edu

Received 29 September 2011; Accepted 18 October 2011

Academic Editors: J. L. Gonzalez-Andujar and N. Maruyama

Copyright (c) 2012 William D. Sommers IV et al. This is an open access article distributed under the Creative Commons Attribution License, which permits unrestricted use, distribution, and reproduction in any medium, provided the original work is properly cited.

\begin{abstract}
A three-year study was conducted in the Chihuahuan Desert in Southwestern New Mexico to evaluate the effectiveness of revegetating a dryland pasture that was heavily infested with yellow starthistle within the context of the successional weed management model. A prescribed burn treatment of the entire study site (designed disturbance) was followed by single-entry revegetation (controlled colonization) and weed suppression (controlled species performance) treatments. Four native perennial grass species were paired with 4 yellow starthistle suppression treatments. We conclude that an integrated, single-entry approach failed to effectively revegetate yellow starthistle-infested dryland pasture in the Chihuahuan Desert, primarily due to a historic severe drought that occurred soon after grasses were seeded. Different strategies and tactics will be required to manage yellow starthistle in the Southwestern USA than have been previously applied in other areas.
\end{abstract}

\section{Introduction}

Yellow starthistle (Centaurea solstitialis) is an exotic annual forb that was introduced into California in the mid-1800's and has since become widely distributed across the Western USA [1-3]. Legally designated as a noxious weed in 12 western states, yellow starthistle is a major problem in California where it has infested up to 22 million acres or about $22 \%$ of the state's surface area [4]. In addition to expanding rapidly in the Pacific Northwest states, yellow starthistle has invaded several areas in Arizona and New Mexico, including Grant County in Southwestern New Mexico where approximately 500 acres have been invaded [5].

The greatest concerns about yellow starthistle are its invasive characteristics and economical and ecological impacts [6]. On range and pasture lands, yellow starthistle infestations have formed tall dense stands that reduced forage production [7] and displaced native plants $[8,9]$. Factors contributing to its success as an invasive weed include ability to germinate during the spring, summer, and fall, a spiny seedhead in the reproductive phase, high seed production, and the development of a deep taproot. As an annual plant, yellow starthistle depends exclusively on seed production for population survival and spread. On average, seed production ranges from about 35 to over 80 achenes per seedhead [10], and a single large plant can produce over 100,000 seeds [2, 11]. Thus, effective yellow starthistle management requires suppression of seed production, combined with the establishment of competitive, desirable vegetation [12]. Although research projects have investigated various methods to control yellow starthistle in Northern California [9-13], research has not addressed yellow starthistle management in the Chihuahuan Desert region. Selection and success of the proper control options depends on a variety of ecological site-specific factors (e.g., 
elevation, soil type, temperature, precipitation patterns). Our objective was to evaluate a three-step approach for yellow starthistle management in the Chihuahuan Desert of Southwestern New Mexico based on a successional weed management model described in Sheley et al. [14]. Although our approach involved three stages, our aim was to apply each step as a single-entry in a planned, strategic sequence to discover which combination of treatments was most effective in controlling yellow starthistle, both ecologically and economically $[15,16]$.

\section{Methods}

2.1. Study Area. A field experiment was conducted in the Cliff-Gila Valley, New Mexico from 2002 to 2005 in a formerly cultivated 40.5 ha dryland pasture that was severely infested with yellow starthistle. At the onset of the study, a heavy accumulation of dead yellow starthistle plants occupied the study site. In March 2002, we used the dry weight rank and comparative yield methods [17] to estimate that yellow starthistle composition was $>99 \%$, with $2,100 \mathrm{~kg} / \mathrm{ha}$ of plant material attributed to yellow starthistle necrobiomass [5]. Field bindweed (Convolvulus arvensis L.) emerged as a subdominant weed species during the late-summer months. Study site elevation was approximately $1,370 \mathrm{~m}$ and the soil was a Manzano loam. Mean annual precipitation is approximately $380 \mathrm{~mm}$ with the majority occurring in the form of heavy convective summer thunderstorms, known locally as the "summer monsoon"; precipitation was well below average during the first 2 years of this study (Table 1).

2.2. Designed Disturbance (Prescribed Burn). Before reseeding and yellow starthistle suppression treatments, a prescribed burn served as a "set-up treatment" and designed disturbance to (1) remove the dense buildup of yellow starthistle necrobiomass (i.e., $>99 \%$ species composition and $2,100 \mathrm{~kg} / \mathrm{ha}$ ), (2) prepare the study site for native grass seeding, (3) kill yellow starthistle seeds, and (4) stimulate germination of surviving starthistle seeds in anticipation of treating emerging rosettes with herbicides. On April 24, 2002, the entire study area was burned in a collaborative effort involving the Grant County Cooperative Extension Service, U.S. Forest Service, New Mexico State Forestry, CliffGila Volunteer Fire Department, and the private landowner.

2.3. Experimental Design. The experiment was arranged in a completely randomized split-plot design. Native perennial grassess were main plots, while weed suppression treatments ( $n=4$ plus a control) were subplots nested within each seeding main plot. Native perennial grasses were seeded in $20,9 \times 25 \mathrm{~m}$ main plots; weed suppression treatments were applied within $100,5 \times 9 \mathrm{~m}$ subplots. Each treatment combination was replicated four times. Canopy cover of seeded grasses and density and canopy cover of yellow starthistle were measured as response variables across a 3year period. A 2-m buffer zone surrounded each main plot where yellow starthistle was controlled by periodic mowing and applications of glyphosate.
TAble 1: Precipitation ( $\mathrm{mm}$ ) received in Cliff, New Mexico during the yellow starthistle revegetation field experiment and annual percent of long-term average (source: National Climatic Data Center).

\begin{tabular}{lcccc}
\hline \multirow{2}{*}{ Season } & \multicolumn{4}{c}{ Precipitation } \\
& 2002 & 2003 & 2004 & 2005 \\
\hline January-March & 23 & 40 & 96 & 181 \\
April-June & 4 & 9 & 84 & 30 \\
July-September & 202 & 69 & 189 & a \\
October-December & 75 & 58 & 85 & a \\
Total & 304 & 176 & 454 & - \\
\% Mean annual & $80 \%$ & $46 \%$ & $119 \%$ & - \\
\hline
\end{tabular}

${ }^{a}$ Research completed in April 2005.

2.4. Controlled Colonization (Reseeding). The following four perennial grass species were seeded using the no-till drill method: alkali sacaton (Sporobolus airoides), bottlebrush squirreltail (Elymus elymoides), galleta (Pleuraphis jamesii), and western wheatgrass (Pascopyrum smithii). These grasses were selected because they exhibited contrasting growth habits (rhizomatous versus caespitose) and growing seasons (warm versus cool) and were compatible with the intended use, soil, and climate characteristics of the study site [18]. The ecological site guide for this area confirmed that these four species were present in the historic plant community, with western wheatgrass, squirreltail, and galleta occurring in considerable amounts (i.e., $>10 \%$ composition).

All grass species were seeded in mid-July 2002 after summer monsoon storms began and when there were few yellow starthistle plants visible on the study site (i.e., about 3 months after the prescribed burn in late-April 2002). A no-till rangeland drill was used to seed grasses at the following rates ( $\mathrm{kg}$ PLS/ha): 0.9, alkali sacaton; 6.4, bottlebrush squirreltail; 7.6, galleta; 10.1, western wheatgrass. Seeding depths were $0.6 \mathrm{~cm}$ for alkali sacaton and galleta and $1.3 \mathrm{~cm}$ for the larger seeds of bottlebrush squirreltail and western wheatgrass (USDA NRCS Arizona Range Planting Specifications, 2000). These rates were consistent in that each provided approximately 215 pure live seeds $/ \mathrm{m}^{2}$. Grass seed was sown in 8 rows spaced $1 \mathrm{~m}$ apart, along the length of each main plot. Control plots were not seeded, treated, or tilled. A two-strand electric fence was erected along the perimeter of the study area to exclude livestock grazing.

2.5. Controlled Species Performance (Suppression). Yellow starthistle suppression treatments were 2,4-D applied at $2.24 \mathrm{~kg}$ ae$/ \mathrm{ha}$, clopyralid applied at $0.14 \mathrm{~kg}$ ae$/ \mathrm{ha}$, mowing to a height of $10 \mathrm{~cm}$ [19], and goat grazing (four goats $/ 45 \mathrm{~m}^{2} / 24$ hours). Herbicides were applied on April 23, 2003 (i.e., 1 year after the prescribed burn, about 9 months after grass reseeding) with a $\mathrm{CO}_{2}$ pressurized backpack sprayer and a $3 \mathrm{~m}$ boom when most yellow starthistle plants were in the rosette stage (Table 2). A nonionic surfactant was added to both herbicides to aid absorption, and application occurred in the early morning (0600 to 0900) when winds were calm ( 0 to $8 \mathrm{~km} / \mathrm{hr}$ ). Both herbicides were selective for broadleaf 
TABLE 2: Chronology of single-entry treatments for yellow starthistle revegetation field experiment, conducted 2002-2005 in Cliff, New Mexico.

\begin{tabular}{|c|c|c|}
\hline Date & Yellow starthistle growth stage & Treatment \\
\hline April 24, 2002 & Skeleton/seedling/rosette & $\begin{array}{c}\text { Prescribed burn } \\
\left(_{\text {Designed disturbance })^{\mathrm{a}}}\right.\end{array}$ \\
\hline July 17-20, 2002 & None present ${ }^{\mathrm{b}}$ & $\begin{array}{l}\text { Perennial grass reseeding } \\
{\text { (Controlled colonization })^{\mathrm{a}}}\end{array}$ \\
\hline April 23, 2003 & Seedling/rosette & 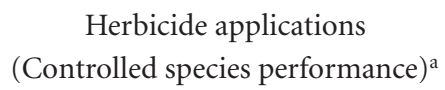 \\
\hline June 13-19, 2003 & Early flowering & $\begin{array}{c}\text { Goat grazing and mowing } \\
\text { (Controlled species performance) }^{\mathrm{a}}\end{array}$ \\
\hline
\end{tabular}

${ }^{\mathrm{a}}[14]$

${ }^{\mathrm{b} C o m b i n e d ~ e f f e c t ~ o f ~ d r o u g h t ~ a n d ~ p r e s c r i b e d ~ b u r n . ~}$

TABLE 3: Yellow starthistle canopy cover (\%) and density (plants $/ \mathrm{m}^{2}$ ) averaged over all seeded grass treatments in Cliff, New Mexico (20032005).

\begin{tabular}{|c|c|c|c|c|c|c|}
\hline \multirow{2}{*}{ Treatment } & \multicolumn{3}{|c|}{ Canopy cover ${ }^{\mathrm{a}}$} & \multicolumn{3}{|c|}{ Density } \\
\hline & $2003^{\mathrm{b}}$ & 2004 & 2005 & $2003^{\mathrm{b}}$ & 2004 & 2005 \\
\hline $2,4-\mathrm{D}$ & $11 \mathrm{a}$ & $71 \mathrm{a}$ & $61 \mathrm{a}$ & $116 a$ & $770 \mathrm{a}$ & $1997 \mathrm{a}$ \\
\hline Clopyralid & $13 a$ & $43 b$ & $42 b$ & $125 \mathrm{a}$ & $731 \mathrm{a}$ & $973 b$ \\
\hline Control & $16 \mathrm{a}$ & $61 c$ & $41 \mathrm{~b}$ & $119 a$ & $1684 b$ & $628 \mathrm{~b}$ \\
\hline Goat grazing & $18 \mathrm{a}$ & $64 \mathrm{ac}$ & $44 \mathrm{~b}$ & $130 \mathrm{a}$ & $1561 b c$ & $757 b$ \\
\hline Mowing & $15 a$ & $60 c$ & $43 \mathrm{~b}$ & $107 \mathrm{a}$ & $1262 \mathrm{c}$ & $681 b$ \\
\hline
\end{tabular}

${ }^{a}$ Cover data were log-transformed, but are presented as original values.

${ }^{\mathrm{b}}$ Cover and density data were collected after burning but before suppression treatments in April 2003.

Means followed by the same letter within a year do not differ, $\operatorname{LSD}(P>0.05)$.

species and less likely to injure monocot seedlings at the application rates used in this study. In addition, clopyralid was selected for its pre- and postemergent activity so it could be compared to 2,4-D which has only postemergent effects [20]. Single applications of clopyralid have been highly effective in controlling dense yellow starthistle infestations in California $[9,20]$.

Mowing and goat grazing were applied on June 1319, 2003 when yellow starthistle had bolted and a small percentage (2 to 5\%) had begun to flower (Table 2). Subplots were mowed once to a height of $10 \mathrm{~cm}$ with an all terrain mower [5]. Benefield et al. [19] showed that mowing erect yellow starthistle plants to a height of $10 \mathrm{~cm}$ during the early flowering stage was the most effective mowing treatment in their study. Goats were used because they effectively reduced yellow starthistle via controlled grazing in previous studies [21]. Wire panels created temporary pens for four goats to graze each $5 \times 9 \mathrm{~m}$ subplot for 24 hours. This treatment was effective at defoliating nearly all yellow starthistle plants, in addition to trampling smaller plants and rosettes.

2.6. Data Collection and Analysis. Treatment effects were measured in April or May from 2003 to 2005. In April 2003 , baseline data were collected within eight $40 \times 40 \mathrm{~cm}$ quadrats per subplot before herbicides were applied. Each quadrat was placed along each seeded grass row at a random location within the subplot. Within each quadrat we estimated canopy cover (\%) of seeded grasses and yellow starthistle and yellow starthistle density (plants $/ 0.16 \mathrm{~m}^{2}$ ).
Canopy cover was classified in one of six cover classes, ranging from 0 to $100 \%$ [22] in 800 permanent quadrats that were revisited for 3 consecutive years. Yellow starthistle density increased dramatically in 2004 and 2005 (Table 3). To reduce sampling time needed to count each individual in 800 , $0.16 \mathrm{~m}^{2}$ quadrats, yellow starthistle density was estimated within $5 \times 30 \mathrm{~cm}$ subquadrats in 2004 and 2005 .

Data were analyzed using ANOVA. When the F-test was significant $(P<0.05)$, means were further analyzed using Fisher's protected LSD. Before analysis, validation of normality and equality of variances were evaluated using histograms, box plots, and residual plots. We log-transformed cover data prior to using ANOVA because variances were found to be heterogeneous $[23,24]$. Actual cover values are reported in tables.

\section{Results}

3.1. Designed Disturbance (Prescribed Burn). The significant buildup of dense yellow starthistle necrobiomass was sufficient to carry a fire in April 2002 that produced up to $1 \mathrm{~m}$ high flames. This fire reduced yellow starthistle cover and biomass from $>99 \%$ species composition and $2,100 \mathrm{~kg} / \mathrm{ha}$ to ocular estimates of near $0 \%$ species composition and $0 \mathrm{~kg} / \mathrm{ha}$. Yellow starthistle rosettes did not emerge until spring 2003.

3.2. Controlled Colonization (Reseeding). Establishment of the seeded grasses was initially assisted by favorable precipitation during the 3-month period immediately following 
TABLE 4: Seeded grass canopy cover (\%) averaged over all yellow starthistle suppression treatments in Cliff, New Mexico (measured in April or May, 2003-2005).

\begin{tabular}{lccc}
\hline Seeded grass & \multicolumn{3}{c}{ Canopy cover $^{\mathrm{a}}$} \\
& 2003 & 2004 & 2005 \\
\hline Control & $0 \mathrm{a}$ & $0 \mathrm{a}$ & $0 \mathrm{a}$ \\
Galleta & $0.7 \mathrm{~b}$ & $1.1 \mathrm{bc}$ & $2.9 \mathrm{bc}$ \\
Alkali sacaton & $0 \mathrm{a}$ & $0 \mathrm{a}$ & $0 \mathrm{a}$ \\
Squirreltail & $0.8 \mathrm{~b}$ & $0.6 \mathrm{ab}$ & $1.3 \mathrm{ab}$ \\
Western wheatgrass & $0.8 \mathrm{~b}$ & $2.5 \mathrm{c}$ & $3.5 \mathrm{c}$ \\
\hline
\end{tabular}

${ }^{a}$ Cover data were log-transformed, but are presented as original values. Means followed by the same letter within a year do not differ, LSD $(P>$ $0.05)$.

seeding (i.e., July to September 2002 was 53\% of mean annual precipitation, Table 1). However, subsequent grass development and establishment was hindered by a historic severe drought that occurred throughout all of 2003 (total annual precipitation for 2003 was $46 \%$ of the mean annual precipitation, Table 1). In 2003, mean canopy cover was $<1 \%$ for all seeded grass species (Table 4). Both galleta (warm season, rhizomatous) and western wheatgrass (cool season, rhizomatous) had established at around 3\% canopy cover by 2005 (Table 4). Squirreltail, a cool season bunchgrass, had established poorly in 2005 ( $\sim 1 \%$ canopy cover), and alkali sacaton, a warm season bunchgrass, did not establish at all.

\subsection{Controlled Species Performance (Suppression). After the} prescribed burn and before suppression treatments were applied, mean yellow starthistle cover (14\%) and density $\left(120\right.$ plants $\left./ \mathrm{m}^{2}\right)$ did not differ across all plots in 2003 (Table 3). In both 2004 and 2005, the main effect for suppression treatments was highly significant $(P<0.01)$ for yellow starthistle cover and density, with no significant interaction with seeded grass treatments. By 2004, overall mean yellow starthistle cover had increased to $60 \%$ and density had increased 10 -fold to 1,202 plants $/ \mathrm{m}^{2}$. By 2005 , yellow starthistle mean canopy cover decreased to $46 \%$, and mean density had decreased to 1,007 plants $/ \mathrm{m}^{2}$ which may indicate that yellow starthistle density had reached a selfthinning threshold. A much more favorable trend in total precipitation (and especially cool season precipitation) likely influenced the higher yellow starthistle cover and density in 2004 and 2005 compared to 2003 (Table 1).

In 2004, both herbicides reduced yellow starthistle density by $>50 \%$ compared to the untreated control (Table 3 ). Yellow starthistle cover, on the other hand, was impacted differently by the two herbicides. The 2,4-D treatment resulted in highest mean yellow starthistle cover (71\%), whereas clopyralid treatment had the lowest overall cover (43\%). By 2005, yellow starthistle density and cover were similar in all plots (including control plots), except for the 2,4-D treatment, which had the highest density and cover of all plots (Table 3).

Mowing initially reduced 2004 yellow starthistle density by $25 \%$ compared to control plots (Table 3 ); however, cover in mowed plots was not different from control plots. Mowed and control plots contained similar cover and density levels of yellow starthistle by 2005 . Goats temporarily defoliated the majority of yellow starthistle plants in June 2003, however, their impact was temporary and similar to mowing results.

\section{Discussion}

4.1. General Approach. Although integrated weed management usually involves a multiyear approach involving a combination of multiple entry control techniques, singleentry methods have recently been successfully used to revegetate rangelands infested with other knapweeds (e.g., $C$. repens, C. maculosa) $[15,16]$. Our study used various singleentry treatments designed to suppress yellow starthistle in the short term (burning, herbicides, mowing, grazing), in combination with 4 native perennial grasses that were seeded to compete with yellow starthistle for resources (water, space, sunlight, etc.) in the long term. This study was the first (to our knowledge) to test the successional weed management model [14] of designed disturbance, controlled colonization, and controlled species performance to manage yellow starthistle in the Chihuahuan Desert. We could not have anticipated conducting our study during one of the most severe droughts in recorded history for this ecoregion [25]. Because precipitation is a major driver of plant succession in the arid and semiarid ecoregions such as the Chihuahuan Desert [26], our objective of using an integrated single-entry approach to revegetate a dryland area infested with yellow starthistle did not succeed.

4.2. Designed Disturbance (Prescribed Burn). Spring burning in 2002 effectively removed yellow starthistle necrobiomass from the study site which facilitated the reseeding of perennial grasses the following summer. Fire temperature during the prescribed burn was insufficient to kill most yellow starthistle seeds within the soil as evidenced by the proliferation of yellow starthistle rosettes in spring 2003. Burning was an important part of the study design, as some form of disturbance was required to selectively redirect the plant dynamics of the site [27].

4.3. Controlled Colonization (Reseeding). Introducing and establishing competitive vegetation is critical for successful long-term management of weed infestations and the restoration of desirable plant communities when large areas are dominated by invasive species or when weed control efforts disturb large areas $[28,29]$. Both of these situations occurred during our study due to the heavy initial yellow starthistle infestation prior to the prescribed burn, and the postdisturbance caused by the prescribed burn. Successful revegetation programs should include a combination of species adapted to the study area with different growth forms and growing seasons to maximize resource capture across space and time [14]. Various native and nonnative perennial grass species have been used in revegetation projects to successfully compete with noxious weeds $[13,15,30,31]$. The native grasses used in our study provided the following warm season (WS)/cool season (CS), and rhizomatous (R)/bunchgrass 
(B) combinations: WS/B (alkali sacaton), CS/B (squirreltail), WS/R (galleta), and CS/R (western wheatgrass). Our aim in using grasses with 2 different growing seasons and growth forms was to test various combinations of temporal and spatial growth dynamics of controlled colonization. Sodforming grasses like western wheatgrass are considered good choices for revegetation when noxious weeds are a factor in site rehabilitation [32]. Further, western wheatgrass is a cool season species that begins growing in the fall if soil moisture is adequate [18], which was a desirable growth characteristic for directly competing against a cool season annual like yellow starthistle. This could help explain why western wheatgrass was the most successful grass of the four tested in this study.

4.4. Controlled Species Performance (Suppression). We hypothesized that clopyralid would control yellow starthistle seedlings throughout the growing season due to its residual preemergent properties. DiTomaso et al. [20] found that clopyralid applied at $0.1 \mathrm{~kg}$ ae/ha during the late-rosette stage provided nearly complete control of yellow starthistle for at least one growing season in central California. Our results with clopyralid were not as impressive as those reported in DiTomaso et al. [20]. Clopyralid effectiveness may have been limited in our study due to the chemical being applied during a long dry period with only $9 \mathrm{~mm}$ of precipitation (i.e., from April to June 2003, Table 1). With so little rain several months after application, initial clopyralid activity was limited to damaging existing rosettes.

Clopyralid was more effective than 2,4-D in controlling yellow starthistle. Clopyralid did not defoliate field bindweed (Convolvulus arvensis), a member of the Convolvulaceae family that was present during the summer months. In contrast, one month after application, 2,4-D had temporarily "burned off" most field bindweed leaves. Short-term defoliation of this warm season perennial dicot apparently opened up germination sites and provided additional resources (e.g., sunlight, water, minerals) for yellow starthistle establishment within the 2,4-D treatment subplots. Moreover, yellow starthistle seedlings are especially susceptible to shading [33] and may have been limited by the summer-long presence of field bindweed as well as by the selective suppression effect of clopyralid.

Mowing has been used successfully to control yellow starthistle when it begins to flower [10, 18]. Benefield et al. [19] reported three stipulations for mowing yellow starthistle: (1) it must be timed with the early flowering stage ( 2 to $5 \%$ bloom), (2) it must be performed on erect growth forms of yellow starthistle, and (3) it must be repeated as necessary depending on the unique characteristics of the site. We followed the first two stipulations of Benefield et al. [19], but the third was contrary towards applying each treatment as a single-entry, a primary goal of our study. An additional mowing later in 2003 may have further reduced yellow starthistle seed production [19].

In California, goats and cattle have been used to suppress yellow starthistle later in the growing season when it is bolting, spiny, or beginning to flower $[11,21,34]$. In our study, goats temporarily defoliated the majority of yellow starthistle plants in June 2003, but considerable regrowth during July and August and rosette emergence in 2004 mostly negated the effects of 2003 grazing. By 2005, single-entry goat grazing had not significantly reduced cover or density of yellow starthistle compared to control plots (Table 3).

4.5. Precipitation. Although all ecological site factors (i.e., soils, topography, temperature, precipitation, aspect, elevation) influence plant dynamics, the most important ecological site characteristic driving plant succession in the arid and semiarid regions of the Southwestern USA is timing and amount of precipitation [26]. Summer monsoon precipitation (i.e., $202 \mathrm{~mm}$ received from July-Sept, 2002) was highly favorable for grass seed germination, but a severe drought from Oct. 2002 until Jan. 2004 was highly unfavorable for grass establishment or for the efficacy of clopyralid on emerging yellow starthistle seedlings and rosettes. The 2002/2003 drought was similar to a severe drought that occurred in the Southwestern USA in the 1950s, except that the 2002/2003 drought also consisted of anomalously high temperatures across the Southwestern USA [25]. These combined factors likely exacerbated transpiration and respiration losses of seedling perennial grasses. Following drought, winter precipitation in 2004 and 2005 became highly favorable towards the proliferation of cool season annuals, which corresponded with increasing levels of yellow starthistle in all plots in 2004 and 2005.

\section{Conclusions}

This study used the successional weed management model devised by Sheley et al. [14] to apply cultural, chemical, and mechanical methods with the goal of revegetating yellow starthistle-infested dryland using a single-entry approach $[15,16]$. Treatments were applied sequentially to initiate "designed disturbance" (prescribed burning) followed by "controlled colonization" (seeding native grasses) and "controlled species performance" (using herbicides, goats, and mowing to suppress yellow starthistle). Our study failed mostly because it occurred during one of the more severe drought events in recorded history for the Southwestern USA The protocols and techniques that have proven successful for one ecotype cannot necessarily be applied in another. In the Chihuahuan Desert of New Mexico, stochastic drought and moisture events favorable to yellow starthistle and unfavorable to grass establishment limited the ability of one-time suppression treatments to effectively manage this invasive plant. We conclude that adaptive management will be necessary to deal with invasive plant infestations in the desert regions of the Southwestern USA in light of the stochastic nature of precipitation patterns common in these arid- and semiarid ecosystems.

\section{Management Implications}

While researchers are constrained by the rigors of experimental protocols designed to discover the efficacy of various treatments and accomplish specific research objectives, land 
managers have much more flexibility to apply proven techniques to adaptively manage invasive plants. Using the results of this and previous experiments, we offer the following "implications for practice" that managers could consider as part of an adaptive management approach to manage yellow starthistle in arid and semiarid regions such as the Chihuahuan Desert.

(i) Site-specific knowledge will be essential for noxious weed management projects in arid and semiarid climates. It will be especially important to closely monitor episodic precipitation and drought events and the concomitant response of yellow starthistle to those events. Yellow starthistle in our study was highly opportunistic, germinating and establishing in the fall, spring, and even during the summer months.

(ii) A single-entry approach failed under the climatic and ecological conditions of this study. Proven suppression treatments (e.g., clopyarlid, mowing, grazing) need to be applied in combination with one another or as multiple entries of the same treatment toward the strategic goal of steadily reducing yellow starthistle seed production and the seedbank.

(iii) Our reseeding efforts failed because of an epic drought that no one could have predicted. Still, reseeding efforts, like suppression efforts, can opportunistically be attempted in response to more favorable moisture conditions. In the region of this study, drought could be considered an opportunity (disturbance) to initiate a restoration project based on the successional weed management model.

(iv) We used native grass species in this study, however, an alternative would have been to use drought tolerant nonnative grasses. Managers will have to weigh the tradeoffs of using native grasses against a higher risk of failure (i.e., compared to using nonnative, noninvasive grasses). Further, consideration should be given to planting a variety of different species that provide year-round competition with noxious weeds.

(v) It will take several years of adaptive management to significantly reduce a yellow starthistle population with a large residual seedbank. Patience is a prerequisite towards managing highly invasive plants, and a fully equipped toolbox is a requirement.

\section{Acknowledgments}

This research was funded by the USDA Institute for Future Agriculture and Food Systems and the USFS Rocky Mountain Research Station, Albuquerque, New Mexico. The authors would specifically like to thank the private landowner, in addition to those who provided technical and field assistance: Dr. Kirk McDaniel, Judy Ward, Kandres Halbrook, Manny Gonzales, Garrett Timmons, Elizabeth Majchrowicz, Jack Noel, Herbert Holmes, Casey Stephenson, Donna King, Dr. Steve Smith, Rebecca Garvoille, Christina Contreras, Libby Landeen, Emiko Ariyasu, John Hays Jr., and Mary Hershdorfer.

\section{References}

[1] D. M. Maddox, A. Mayfield, and N. H. Poritz, "Distribution of yellow starthistle (Centaurea solstitialis) and Russian knapweed (Centaurea repens)," Weed Science, vol. 33, pp. 315-327, 1985.

[2] R. L. Sheley, L. L. Larson, and J. S. Jacobs, "Yellow starthistle," in Biology and Management of Noxious Rangeland Weeds, R. L. Sheley and J. K. Petroff, Eds., pp. 408-416, Oregon State University Press, Corvallis, Ore, USA, 1999.

[3] M. J. Pitcairn, S. Schoenig, R. Yacoub, and J. Gendron, "Yellow starthistle continues its spread in California," California Agriculture, vol. 60, pp. 83-90, 2006.

[4] M. J. Pitcairn, R. A. O'Connell, and J. M. Gendron, "Yellow starthistle: survey of statewide distribution," in Biological Control Program Annual Summary, 1997, D. M. Woods, Ed., pp. 64-66, California Department of Food and Agriculture, Plant Health and Pest Prevention Services, Sacramento, Calif, USA, 1998.

[5] W. D. Sommers IV, An investigation of community-based and integrated yellow starthistle management in southwestern New Mexico, M.S. thesis, The University of Arizona, Tucson, Ariz, USA, 2005.

[6] A. J. Eagle, M. E. Eiswerth, W. S. Johnson, S. E. Schoenig, and G. C. Van Kooten, "Costs and losses imposed on California ranchers by yellow starthistle," Rangeland Ecology and Management, vol. 60, no. 4, pp. 369-377, 2007.

[7] L. W. Lass, J. P. McCaffrey, D. C. Thill, and R. H. Callihan, Yellow starthistle: Biology and Management on Pasture and Rangeland, vol. 805 of University of Idaho Cooperative Extension Bulletin, University of Idaho, College of Agriculture, Idaho, Idaho, USA, 1999.

[8] R. L. Sheley and L. L. Larson, "Comparative growth and interferance between cheatgrass and yellow starthistle seedlings," Journal of Range Management, vol. 47, no. 6, pp. 470-474, 1994.

[9] J. M. DiTomaso, G. B. Kyser, S. B. Orloff, and S. F. Enloe, "Integrated strategies offer site-specific control of yellow starthistle," California Agriculture, vol. 54, pp. 30-36, 2000.

[10] C. B. Benefield, J. M. DiTomaso, G. B. Kyser, and A. Tschohl, "Reproductive biology of yellow starthistle: maximizing lateseason control," Weed Science, vol. 49, no. 1, pp. 83-90, 2001.

[11] J. M. DiTomaso, "University of California Weed Research and Information Center," 2011, http://wric.ucdavis.edu.

[12] S. F. Enloe, J. M. DiTomaso, S. Orloff, and D. Drake, "Integrated strategies for the attrition of yellow starthistle on Northern California rangeland," Proceedings of the California Weed Science Society, vol. 52, pp. 31-34, 2000.

[13] S. F. Enloe, J. M. Ditomaso, S. B. Orloff, and D. J. Drake, "Perennial grass establishment integrated with clopyralid treatment for yellow starthistle management on annual range," Weed Technology, vol. 19, no. 1, pp. 94-101, 2005.

[14] R. L. Sheley, T. J. Svejcar, and B. D. Maxwell, "A theoretical framework for developing successional weed management strategies on rangeland," Weed Technology, vol. 10, no. 4, pp. 766-773, 1996.

[15] R. L. Sheley, J. S. Jacobs, and D. E. Lucas, "Revegetating spotted knapweed infested rangeland in a single entry," Journal of Range Management, vol. 54, no. 2, pp. 144-151, 2001.

[16] R. L. Sheley, "Revegetating Russian knapweed (Acroptilon repens) and green rabbitbrush (Ericameria teretifolia) infested rangeland in a single entry," Weed Science, vol. 55, no. 4, pp. 365-370, 2007. 
[17] D. W. Despain, P. R. Ogden, G. B. Ruyle, and E. L. Smith, "Some methods for monitoring rangelands and other natural area vegetation," The University of Arizona cooperative extension report number 9043, 1997.

[18] J. Stubbendieck, S. L. Hatch, and C. H. Butterfield, North American Range Plants, University of Nebraska Press, Lincoln, UK, 1997.

[19] C. B. Benefield, J. M. DiTomaso, G. B. Kyser et al., "Success of mowing to control yellow starthistle depends on timing and plant's branching form," California Agriculture, vol. 53, pp. 1721, 1999.

[20] J. M. DiTomaso, G. B. Kyser, S. B. Orloff, S. F. Enloe, and G.A. Nader, "New growth regulator herbicide provides excellent control of yellow starthistle," California Agriculture, vol. 53, pp. 12-16, 1999.

[21] C. D. Thomsen, W. A. Williams, M. Vayssieres, F. L. Bell, and M. R. George, "Controlled grazing on annual grassland decreases yellow starthistle," California Agriculture, vol. 47, pp. 36-40, 1993.

[22] R. Daubenmire, "A canopy-coverage method of vegetational analysis," Northwest Science, vol. 33, pp. 43-64, 1959.

[23] J. H. Zar, Biostatistical Analysis, Prentice Hall, Upper Saddle River, NJ, USA, 4th edition, 1999.

[24] F. L. Ramsey and D. W. Schafer, The Statistical Sleuth: A Course in Methods of Data Analysis, Duxbury, Pacific Grove, Calif, USA, 2002.

[25] D. D. Breshears, N. S. Cobb, P. M. Rich et al., "Regional vegetation die-off in response to global-change-type drought," Proceedings of the National Academy of Sciences of the United States of America, vol. 102, no. 42, pp. 15144-15148, 2005.

[26] J. L. Holechek, R. D. Pieper, and C. H. Herbel, Range Management: Principles and Practices, Prentice Hall, New York, NY, USA, 5th edition, 2003.

[27] J. M. DiTomaso, G. B. Kyser, and M. S. Hastings, "Prescribed burning for control of yellow starthistle (Centaurea solstitialis) and enhanced native plant diversity," Weed Science, vol. 47, no. 2, pp. 233-242, 1999.

[28] L. L. Larson and M. L. McInnis, "Impact of grass seedlings on establishment and density of diffuse knapweed and yellow starthistle," Northwest Science, vol. 63, no. 4, pp. 162-166, 1989.

[29] M. M. Borman, W. C. Krueger, and D. E. Johnson, "Effects of established perennial grasses on yields of associated annual weeds," Journal of Range Management, vol. 44, no. 4, pp. 318322, 1991.

[30] L. J. Benz, K. G. Beck, T. D. Whitson, and D. W. Koch, "Reclaiming russian knapweed infested rangeland," Journal of Range Management, vol. 52, no. 4, pp. 351-356, 1999.

[31] S. F. Enloe, J. M. DiTomaso, S. B. Orloff, and D. J. Drake, "Soil water dynamics differ among rangeland plant communities dominated by yellow starthistle (Centaurea solstitialis), annual grasses, or perennial grasses," Weed Science, vol. 52, no. 6, pp. 929-935, 2004.

[32] R. H. Callihan and J. O. Evans, "Weed dynamics on rangeland," in Noxious Range Weeds, L. F. James, J. O. Evans, M. H. Ralphs, and R. D. Child, Eds., pp. 55-61, Westview Press, Boulder, Colo, USA, 1991.

[33] B. F. Roche Jr., C. T. Roche, and R. C. Chapman, "Impacts of grassland habitat on yellow starthistle (Centaurea solstitialis L.) invasion," Northwest Science, vol. 68, no. 2, pp. 86-96, 1994.

[34] C. D. Thomsen, W. A. Williams, M. R. George, W. B. McHenry, F. L. Bell, and R. S. Knight, "Managing yellow starthistle on rangeland," California Agriculture, vol. 43, pp. 4-7, 1989. 


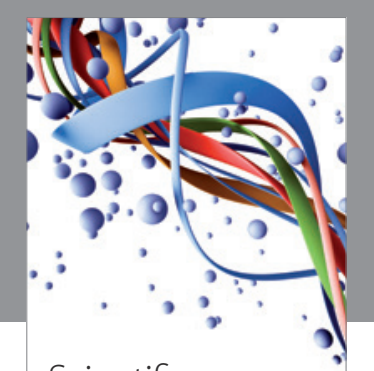

Scientifica
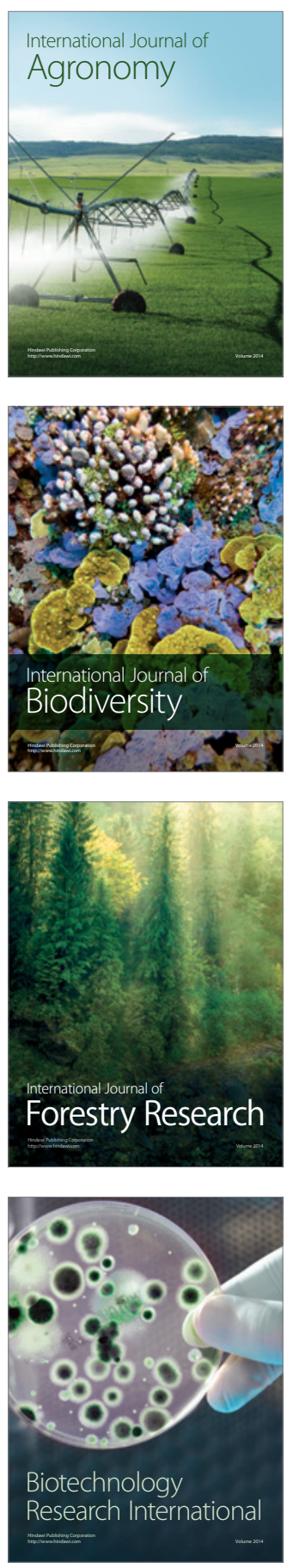
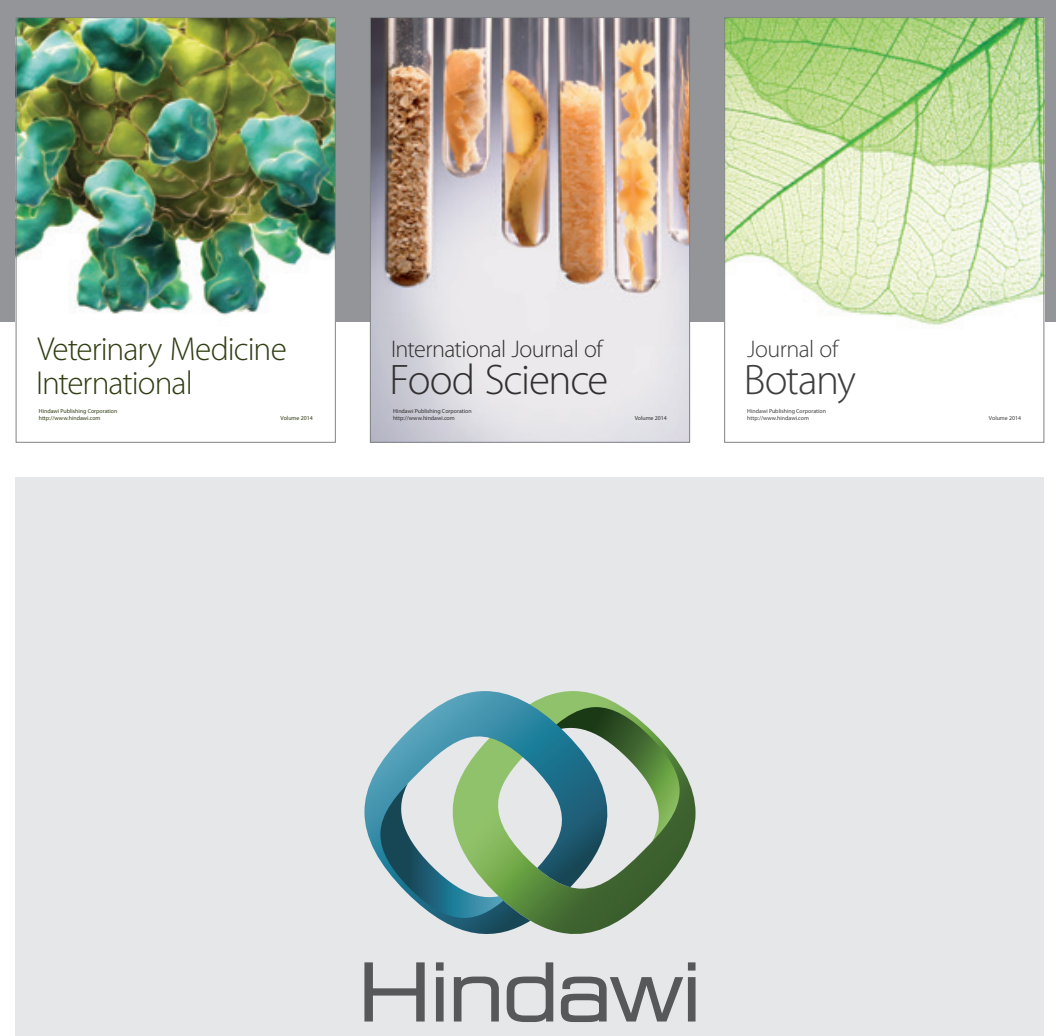

Submit your manuscripts at

http://www.hindawi.com
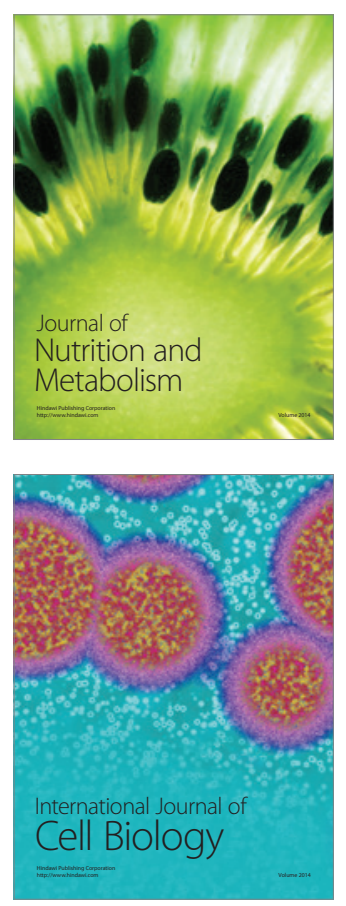
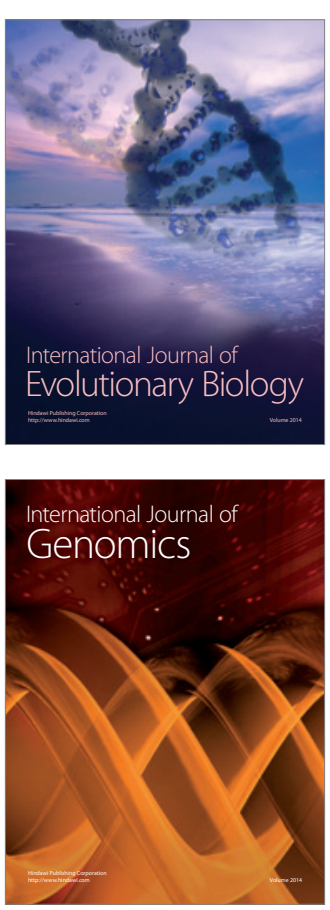
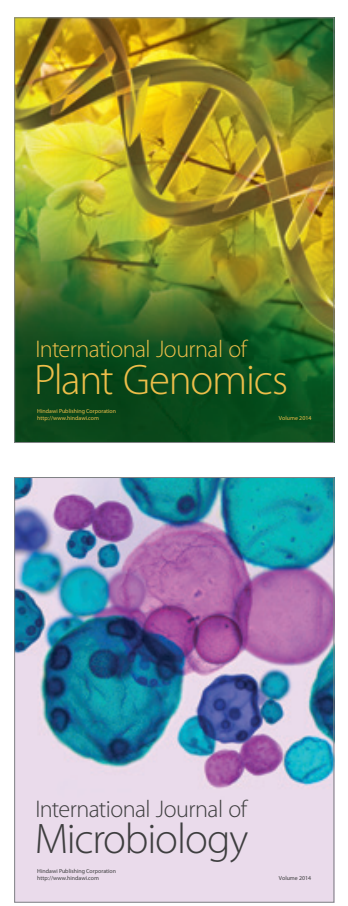

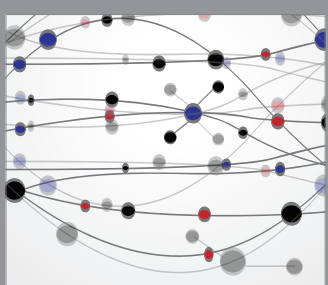

The Scientific World Journal
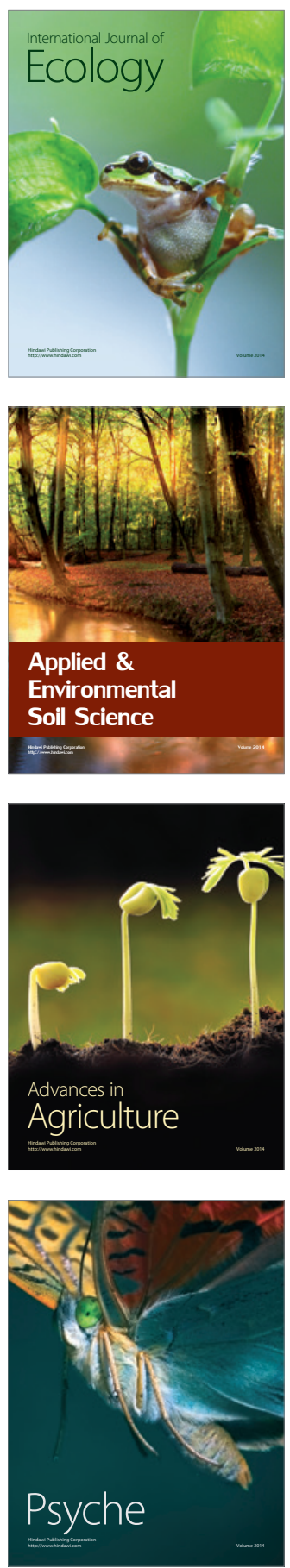